\title{
A ESTRUTURA DO HOMEM INTEGRADO À NATUREZA COMO PRINCÍPIO DA LITERATURA BRASILEIRA CONTEMPORÂNEA
}

\author{
JULIE DORRICO ${ }^{1}$ \\ PUCRS, BRASIL
}

\begin{abstract}
RESUMO: Este artigo tem por objetivo mostrar como que a literatura de autoria indígena brasileira é orientada pelo princípio do homem integrado à natureza. Autores como Sulamy Katy (2011), Kaká Werá Jecupé (2002), Ailton Krenak (2019), Daniel Munduruku (2016) e Renê Khitãulu (2002) são exemplos dessa escrita autorreferenciada em que podem ser encontrados este princípio. A partir das publicações autorais, os escritores indígenas passam a desmistificar noções ossificadas no imaginário nacional como bom selvagem, canibal, vitima passiva e até mesmo de resistente cultural. As análises das obras indígenas revelam que a autoria indígena denota sua singularidade na estrutura do pensamento amerindio e oral, utilizando ferramentas ocidentalizadas como a escrita alfabética e a publicação. Apesar do uso destas ferramentas, conclui-se que há uma diferença notória na literatura de autoria indígena em relação à representação na literatura e na história brasileira do sujeito indígena como tema, uma vez que esta segue o princípio que dicotomiza as relações entre natureza e cultura; e, de modo diametralmente oposto, a literatura indigena exprime em suas obras o valor das relações entre o homem indigena e natureza.
\end{abstract}

PALAVRAS-CHAVE: Literatura indígena. Estrutura. Autoria. Autorreferência. Natureza.

\begin{abstract}
This paper has the purpose of showing how Brazilian Indian authorial literature is oriented for the principle of integration between man and nature. Authors as Sulamy Katy (2011), Kaká Werá Jecupé (2002), Ailton Krenak (2019), Daniel Munduruku (2016) e Renê Khitãulu (2002) are examples of this self-referential writing in which can be found such principle. From authorial publications, Indian writers search de demystification of ossified notions rooted in the national imaginary, as good savage, cannibal, passive victim and even cultural resistant. The theoretical analysis of the Indian works reveal that Indian authorship makes explicit its singularity in the structure of Amerindian thought and orality, by using Western tools like alphabetic writing and publication. However, despite the use of these tools, we can conclude for the existence of a notorious difference of the Indian authorial literature in relation to the traditional representation of Indian subject in the Brazilian literature and history as theme, since this traditional model of Brazilian literature and history assumes the dichotomization of nature and culture. On the counterpoint of such dualism, Indian literature emphasizes in its productions the centrality of these relations between Indian man/woman and nature.
\end{abstract}

KEYWORDS: Indian Literature; Structure; Authorship; Self-Reference; Nature.

\footnotetext{
${ }^{1}$ Macuxi. Doutoranda em Teoria Literária (Pontifícia Universidade Católica do Rio Grande do Sul, Brasil. E-mail: juliedorrico@gmail.com
} 
A "conquista" da América indígena não terminou no século XVI: ela ainda está acontecendo, agora mesmo, enquanto escrevo estas páginas.

Lúcia Sá

\section{Considerações Iniciais}

O epílogo acima de Lúcia Sá, apesar de ter sido registrado em 2012, denota o tempo presente, em que agendas, instituições indigenistas, povos e comunidades indígenas têm seus territórios ameaçados pelo agronegócio, pelo empresariado e pelo próprio Estado. Tais ameaças põem em risco a vida física e a vida simbólica dos povos originários no país; por isso mesmo, este artigo tem por objetivo discutir como a autoria denuncia violências históricas, além de evidenciar a representatividade coletiva e individual desses sujeitos por meio da literatura.

A importância da autoria indígena, em termos de expressão estética e histórica, na literatura brasileira, revela que a tradição ancestral, assentada na oralidade, dialoga com a estrutura ocidental (escrita) sem denegar o estatuto da identidade indígena no impresso, uma vez que usa das narrativas, culturas e cosmologias indígenas como a principal matéria para a produção literária indígena na contemporaneidade.

Nesse sentido, percebe-se na produção autoral dos escritores indígenas o princípio do homem integrado à natureza. Quando Sulamy Katy (2011), Ailton Krenak (2019), Kaká Werá Jecupé (2002), Daniel Munduruku (2016), Renê Khitãulu (2002) publicam seus livros, não deixam de imprimir em suas obras os planos de orientação que conduzem seus modos de vida e espiritualidades e, assim, a partir da enunciação indígena é possível conhecer como dão sentido às relações daí advindas: desde o contato, os mitos, até a publicação do livro como tecnologia para estabelecer um diálogo com a sociedade nacional. $O$ princípio de homem integrado à natureza irá aparecer inexoravelmente na literatura de autoria indígena.

A literatura indígena brasileira nasce para a sociedade envolvente ${ }^{2}$, segundo Almeida e Queiroz (2004), da produção editorial de livros didático-pedagógicos realizada pelas comunidades indígenas em caráter autoral coletivo na década de 1990. Os "livros da floresta" manufaturados nas aldeias envolvem a revitalização das línguas indígenas, o ensino do português como segunda língua, o resgate dos saberes tradicionais para o fortalecimento do protagonismo dos sujeitos e povos indígenas, por meio da educação dentro e fora do contexto da aldeia.

A autoria individual, por outro lado, marca um novo movimento com a publicação da obra de Kaká Werá Jecupé, em 1994, intitulada Oré

\footnotetext{
${ }^{2}$ Wilmar da Rocha D’Angelis (2007, p. 14) informa que à sociedade e cultura não-índia é dado o nome, entre outros, de "sociedade envolvente".
} 
awé roirua'ma: Todas as vezes que dissemos adeus. Esta obra com alcance nacional impulsiona a atuação de outros autores, que passam a ser procurados por editoras privadas, como Daniel Munduruku, nome de maior expressão no movimento literário brasileiro, Eliane Potiguara, Olívio Jekupé - que já publicara em 1993 de forma independente ${ }^{3}$-, Cristino Wapichana, Tiago Hakiy, Yaguarê Yamã, Márcia Kambeba, Auritha Tabajara, Graça Graúna, entre outros ${ }^{4}$.

O contexto histórico revela que a manifestação literária indígena é decorrente das lutas do Movimento Indígena Brasileiro. Este movimento político ensejado nas décadas de 1970-1980 por lideranças e intelectuais indígenas assegurou o capítulo Dos índios na Constituição Federal de 1988 e os desdobramentos daí resultantes, como as legislações que garantem o direito à educação escolar indígena; a Lei 11.645/2008 que torna obrigatório o ensino das culturas afro-indígenas nas disciplinas de História, Literatura e Artes da rede básica. Estes desdobramentos intensificaram a procura por autores e trabalhos indígenas, impulsionando, assim, um mercado editorial em favor desses povos e sujeitos.

A literatura de autoria indígena, além de denotar o orgulho do pertencimento étnico nos textos criativos, passa a questionar a representação realizada na literatura brasileira sobre suas culturas e estruturas. Com efeito, a visão paradigmática e colonizadora sobre os povos ameríndios retrata-os sob o prisma de ingênuos, canibais (CUNHA, 2016, p. 28-50), bons selvagens (MUNDURUKU, 2017, p. 83-84), vítimas passivas e resistentes a tecnologias, línguas e ferramentas não indígenas (SANTOS; FELIPPE, 2018, p. 17-37).

Nesse sentido, a condição autoral indígena colabora para o agenciamento das culturas e sujeitos indígenas, na literatura brasileira, desde seu lugar de fala ou da sua representatividade. Quando se autorrepresentam, identificam-se como humanos, sujeitos, atores, protagonistas e integrantes de uma comunidade étnica da qual são constituintes inextricáveis (Cf.: GRAÚNA, 2013, p. p. 168; MUNDURUKU, 2017, p. 122-123; JEKUPÉ, 2009, p. 13-15; KRENAK apud COHN, 2015, p. 230).

Assim, os povos indígenas, via literatura, mostram que sua estrutura se constitui como uma visão de mundo em que o homem está integrado à natureza, sendo este o ponto fundante da cosmovisão ameríndia e orientadora das produções em caráter estético, opondo-se à visão de homem versus natureza, ou cultura versus natureza, paradigma central do Ocidente.

Uma vez que este artigo reconhece que a literatura brasileira tem caricaturizado a imagem e a significação dos povos indígenas, buscar-se-

\footnotetext{
${ }^{3}$ Olívio Jekupé publicou em 1993 pela João Scortecci Editora, a obra Leópolis Inesquecível. De igual modo, em 1992, Marcos Terena publicou o livro Cidadãos da selva: a história contada pelo outro lado, pelo projeto Futuro Cidadão do Rio de Janeiro, Gráfica JB.

${ }^{4}$ O trabalho de Aline Franca, Daniel Munduruku e Thúlio Dias Gomes (2019) desvela o número de escritores indígenas no Brasil, bem como suas publicações desde monografias, dissertações e teses até livros de literatura, política e antologias. Para maiores informações ver: https://pt.wikibooks.org/wiki/Bibliografia_das_publicações_indígenas_do_Brasil Acesso em 30/07/2019.
} 
á desenvolver a literatura indígena como elemento de crítica e desconstrução dessa imagem. Para tanto, dividimos este artigo em duas partes: a primeira refere-se à representação dos sujeitos indígenas na literatura brasileira canônica e na história oficial; a segunda, por sua vez, trata de uma análise da produção literária de autores indígenas, enfatizando o modo como estes desenvolvem e publicizam as suas relações com a natureza e com a sociedade envolvente.

\section{A representação indígena no paradigma natureza versus cultura}

Os sujeitos e povos originários são caracterizados enquanto fundamentalmente orais. Tal definição não busca enfatizar os mecanismos ou estratégias estéticas utilizadas por esses povos e sujeitos ao longo dos tempos, mas destacar sua marginalidade em relação ao grafocentrismo. A ausência da escrita alfabética nas sociedades tradicionais de um lado, e o agenciamento da temática indígena pela sociedade envolvente, de outro, resultaram na construção de imagens estereotipadas dos povos tradicionais que ecoam até os dias de hoje.

A deterioração da imagem indígena é um projeto que vem desde a colonização atravessando os séculos e prejudicando os povos e sujeitos indígenas em suas relações político-culturais com a sociedade nacional (TREECE, 2008). Prova disso é a negação da espiritualidade indígena realizada pelos jesuítas, de modo violento, que resultou na morte da alma ancestral e o ocultamento dos povos originários como parte constituinte da identidade nacional. Gambini (2000) argumenta que a distorção e a negação da tradição, das histórias, da língua, isto é, da alma indígena, integra um projeto colonizador que destitui o Outro de humanidade para subjugá-lo ao seu olhar, o olhar europeu:

[...] O fato é que o território brasileiro como um todo estava impregnado de sacralidade, porque o homem anterior ao "descobrimento" comungava, ao viver, com a natureza e com tudo que a povoava. Esse tesouro humano, criação lentamente configurada no decorrer de milênios, foi destruído de um só golpe por obras de um olhar estrangeiro que o distorceu e o negou (GAMBINI, 2000, p. 161).

As incompreensões sobre os modos de vida tradicionais dos povos indígenas da ainda "Terra de Santa Cruz" levaram cronistas e historiadores portugueses - em especial Pero de Magalhães Gandavo (1980), com seu Tratado da Terra do Brasil e sua História da Província de Santa Cruz a que Vulgarmente Chamamos Brasil, esta publicada originalmente em 1576 e aquela em 1826 - a reduzir as organizações tupinambá - e posteriormente todos os grupos da costa, seguidos por todos os povos tradicionais -, à ausência de Fé, Lei ou Rei, reiterando sua tese a partir da ausência das letras F, L e R na língua tupi: "[...] A lingua deste gentio pela Costa he, huma: carece de tres letras - scilicet, não se 
acha nella $F$, nem $L$, nem $R$, cousa digna de espanto, porque assi não têm Fé, nem Lei, nem Rei; e desta maneira vivem sem Justiça e desordenadamente" (GANDAVO, 1980, p. 54).

Esse evidente eurocentrismo, ensejado por cronistas e historiadores, projetou uma imagem do Paraíso sobre os povos da costa brasileira e consolidou sobre elas seu projeto colonizatório. Os sujeitos indígenas foram retratados como desorganizados e perdidos - à espera de um rei e um Deus que apresentasse coesão às suas vidas - e os portugueses se viam como salvadores dessas almas. Ainda sobre os povos tupinambás, construiu-se a imagem de canibais, ecos da narrativa dos navegantes e de Hans Staden ${ }^{5}$ que supostamente viu um ritual antropofágico (Cf.: STADEN, 2017, p. 64-80). O olhar europeu, para justificar suas investidas comerciais e religiosas, assumiu-se como a referência paradigmática para os povos "perdidos" do Novo Mundo.

Analisando as imagens construídas sobre os indígenas na história e na literatura, faz-se necessário perceber como o paradigma do Ocidente se manifesta e, contrariamente a ele, como as narrativas indígenas, via literatura, enunciam seu contraponto ao paradigma dominante. $\mathrm{O}$ paradigma ocidental subsume o mundo a uma identidade como essencial para a modernidade, a saber: a do homem, branco, europeu ('euronorcêntrico6'), judaico-cristão. Para Fernandes (2014), a História parece perseguir um único percurso possível:

A história do pensamento social e filosófico da forma como é ensinado hoje permite traçar uma genealogia direta entre a Grécia Clássica e os pensadores Modernos - como se houvesse apenas um percurso possível ao pensamento e o racionalismo moderno ocidental fosse a única maneira viável e legítima de se constituir o saber. Assim, há um continuum entre o mundo Helenístico, o Império Romano, o Renascimento e a Europa Moderna, como se (a) fosse um percurso retilíneo, uniforme e o mundo euronorcêntrico contemporâneo fosse a finalidade última de todos os povos (resultante da retórica da Modernidade); e/ou (b) não fosse possível um pensamento fora dessa noção de paradigma (FERNANDES, 2014, p. 68).

A lógica do Ocidente, nesse sentido, seria universal e racional, por isso mesmo, científica. Ao desprender-se do mito, a ciência ocidentalizada ocuparia lugar central na política, na sociedade e na cultura do mundo moderno, de modo autorreferencial, por ser neutra,

\footnotetext{
${ }^{5}$ História Verdadeira e Descrição de uma Terra de Selvagens, Nus e Cruéis Comedores de Seres Humanos, Situada no Novo Mundo da América, Desconhecida antes e depois de Jesus Cristo nas Terras de Hessen até os Dois Últimos Anos, Visto que Hans Staden, de Homberg, em Hessen, a Conheceu por Experiência Própria e agora a Traz a Público com essa Impressão, também conhecida pelo título Duas Viagens ao Brasil.

${ }^{6} \mathrm{O}$ termo é utilizado por Fernandes (2014) para apontar a centralidade das produções de conhecimento validadas na Europa e nos Estados Unidos, tomadas como superiores aos demais continentes.
} 
impessoal e imparcial. Para Danner,Danner e Bavaresco (2017), a modernidade configura a única referência possível para a legitimação das normas reguladoras da sociedade e da cultura. Conforme os autores:

A modernidade europeia é racional e geradora de racionalização social porque substitui bases essencialistas e naturalizadas por racionalização cultural-comunicativa, por politização radical, por diálogo e interação permanentes como os únicos caminhos e meios da validação das normas, das práticas e das instituições, pondo de lado e prescindindo do dogmatismo; no mesmo sentido, ela substitui a dependência e a férrea imbricação ao contexto, próprios do tradicionalismo e legitimados por este, por formalização, impessoalidade, neutralidade e imparcialidade. Ora, é aqui que a modernidade torna-se autêntico universalismo em termos societais-culturais, antropológico-ontológicos e epistemológico-políticos: dada a centralidade da racionalização culturalcomunicativa, é instituído, na sociedade moderna e a partir dela, o procedimentalismo imparcial, neutro, formal e impessoal como o modo por excelência de método, de práxis e de consciência cognitivo-moral próprias à sociedade moderna (DANNER; DANNER; BAVARESCO, 2017, p. 163).

Os povos indígenas, para esse paradigma moderno, não poderiam ser racionais uma vez que se orientam pelo mito e este se funda na espiritualidade, no campo da metafísica, já superada pela racionalidade. Os saberes, a antropologia e a ontologia dos povos indígenas, nesse sentido, foram assumidos como inferiores, não se encaixando neste padrão ocidentalizado que, a rigor, defende a universalidade do Cristianismo, da escrita alfabética e da língua portuguesa, práticas culturais da metrópole portuguesa que deveriam ser o modelo de vida dos "gentios" e "índios" que aqui habitavam, na visão dos colonizadores, em estado de pobreza física e simbólica:

[...] Não adorão cousa alguma nem têm pera si que há na outra vida gloria pera os bons, e pena para os maos, tudo cuidão que se acaba nesta e que as almas fenecem com os corpos, e assi vivem bestialmente sem ter conta, nem peso, nem medida (GANDAVO, 1980, p. 54).

Ao sujeito indígena convencionou, em razão desse projeto eurocêntrico, reservar-lhe tão somente o espaço da floresta e o tempo do século XVI. A produção epistemológica indígena, nessa esteira, assentada na oralidade e nos saberes ancestrais, foi ignorada e vista como nãocientífica, por não estar escrita e enquadrada dentro dos modelos que a possibilitariam ser chamada de ciência pela modernidade. 
Em contraposição a esse lugar hegemônico que ocupa a produção de saberes do West, argumentam Shohat e Stam (2006) que "[...] O Ocidente, assim como sua contrapartida oriental, é uma construção fictícia baseada em mitos e fantasias" (SHOHAT; STAM, 2006, p. 37). Isto porque, do ponto de vista geográfico, o conceito de "Ocidente" torna-se relativo. Para os autores, o historiador Raymond Williams elencou períodos que colaboraram para a construção histórica do que hoje compreendemos como Ocidente:
a) Divisão do Império Romano em Oriental e Ocidental;
b) A divisão da Igreja em Oriental e Ocidental;
c) A definição do Ocidente como judaico-cristão e o Oriente como muçulmano, hindu e budista;
d) A divisão da Europa pós-guerra entre Ocidente capitalista e Oriente comunista (SHOHAT; STAM, 2006, p. 37).

Concluem os autores, assim, que a política é quem determina as configurações geográficas. Se a compreensão de Ocidente tida hoje é de uma construção essencialista, a noção de povos indígenas deve ser tomada como uma grande invenção de identidade que não se encaixa no projeto de colonização da modernidade.

Em razão disso, é possível compreender por que foi preciso inventar um índio, um bom selvagem, um canibal, uma vítima passiva e um resistente. Tais despersonalizações se explicam dentro do projeto colonizatório, pois assim foi possível levar a cabo o genocídio e roubarIhe seus territórios com apoio da Igreja, do Império e, posteriormente, do Estado-nação; assassinar a identidade e a cultura, através dos tempos, via etnocídio, e, ainda assim, passar a falsa ilusão de que para o bem desses povos era preciso catequizá-los.

Nessa discussão de distintos paradigmas, é importante salientar, ainda, a compreensão de ciência e cosmologia ocidental explicada por Descola (2016). Para o autor, a cosmologia eurocêntrica muitas vezes é assumida como ciência para deslegitimar outras formas de dar sentido ao mundo. Em suas palavras:

Eu não ponho a ciência em dúvida, eu mesmo sou cientista. Acredito que o que faço respeite as regras do método científico, e o que eu digo não é, portanto, um julgamento da ciência. Mas acredito também que muitas vezes confundimos ciência com o que chamamos, em termos científicos, de cosmologia. De que se trata? Trata-se simplesmente da visão de mundo, da maneira como pensamos que nosso mundo está organizado. Quando afirmamos que o mundo se compõe de entidades naturais, de humanos e de objetos artificiais, enunciamos os princípios de uma cosmologia particular, isto é, da nossa. Outros povos não estabelecem tais 


\begin{abstract}
distinções e veem o mundo segundo outras cosmologias. Nossa cosmologia tornou possível a ciência, mas é preciso entender que essa cosmologia não é em si mesma o produto de uma atividade científica. Ela é uma maneira de distribuir as entidades do mundo, ela é o fruto de uma certa época, que permitiu que as ciências se desenvolvessem. Essa cosmologia existe, e isso não é uma crítica à ciência. Mas é preciso admitir que ela não é universal (DESCOLA, 2016, p. 48).
\end{abstract}

A citação acima nos explica como o autor coteja cosmologia e ciência. Nesta passagem podemos perceber a diferença entre as cosmologias ocidental e indígena. Naquela, as entidades naturais se organizam em humanos e objetos artificiais; nesta, tal organização não resume ao homem o estatuto da humanidade, mas o estende para a floresta. Enquanto na visão do ocidente a floresta é tida sob a perspectiva de objeto, de instrumento que está posto para atender às necessidades de civilização e de "progresso" do homem, visão que corresponde ao humanismo; na visão dos povos indígenas, a floresta é assumida como uma entidade com diversos espíritos, sendo, portanto, não humana, mas com humanidade.

Esta diferença crucial justifica por que o projeto da modernidade explora de modo deliberado os recursos naturais em favor da sua economia; e, por outro lado, por que os povos indígenas coabitam a floresta integrando-a e não desmatando-a para fins comerciais. Sua lógica, como argumenta Albert (2002), ao utilizar o povo yanomami oriental e brasileiro como exemplo, é a da economia política da natureza, em que o homem respeita a vida da floresta e assume que cada planta e animal são seres que em um outro tempo já foram humanos mas que agora têm essa forma decorrente da metamorfose na grande mudança dos tempos.

Essa diferença crucial, cosmológica e paradigmática entre Ocidente e povos indígenas do Brasil, é refletida na literatura brasileira, trazendo à tona a questão da representação lançada aos povos originários e seus sujeitos, e como, a partir da autoria, os povos têm se valido da sua estrutura, para mostrar diferentes formas de dar sentido ao mundo desde a sua relação com a natureza de modo integrado (Cf.: ESCOBAR, 2015), ao mesmo tempo que denunciam de modo metalinguístico a violência histórica perpetrada contra eles.

A seguir podemos ver alguns exemplos que figuram na literatura brasileira e que foram determinantes para a construção de algumas imagens dos indígenas no país que perduram até os dias de hoje.

Cunha (2012), em seu ensaio "Imagens de índios do Brasil no século XVI", argumenta que duas imagens prevaleceram e cunharam uma representação aos povos daquela época: a de ingênuo, associada diretamente à nudez; e a de canibal, oriunda dos relatos dos navegantes. Ambas as imagens possuíam solo fértil na literatura dos viajantes, desde Colombo e Américo Vespúcio a Pero Vaz de Caminha, e encontraram nos 
povos do Novo Mundo seu assento mais duradouro: a nudez associada à ideia de inocência.

A segunda, por sua vez, corresponde ao ato ritualístico antropofágico tupinambá, cuja organização religiosa e social girava em torno da vingança, que foi e é estendida de modo deliberado a todos os povos indígenas de modo indistinto.

As incompreensões acerca das tradições dos povos indígenas no século XVI - e posteriormente - não se justificam apenas na diferença cultural entre europeus e povos originários, mas residem fundamentalmente na diferença estrutural que constitui o Ocidente, posto que é a partir dessa identidade moderna - homem, europeu, branco, judaico-cristão -, que se vê superior e se legitima pelo poder bélico, que serão minadas, ainda hoje, diferentes organizações sociais e ontológicas contrárias a ela, seja em caráter físico ou simbólico. A imagem de ingênuo e canibal, embora construída no século XVI, perdura e atravessa os tempos. Outros exemplos de textos fundacionais, que servem para refletirmos sobre o "índio", construídos à luz da lógica ocidental, integram esse projeto de modernidade:

a) a Carta de Pero Vaz de Caminha a el-rei D. Manuel, referindo o descobrimento de uma nova terra e as primeiras impressões da natureza e do aborígene;

b) o Diário de Navegação de Pero Lopes e Sousa, escrivão do primeiro grupo colonizador, o de Martim Afonso de Sousa (1530);

c) o Tratado da Terra Brasil de Pero Magalhães Gândavo (1576);

d) a Narrativa Epistolar e os Tratados da Terra e da Gente do Brasil do jesuíta Fernão Cardim (a primeira certamente de 1583);

e) o Tratado Descritivo do Brasil de Gabriel Soares de Sousa (1587);

f) os Diálogos das Grandezas do Brasil de Ambrósio Fernandes Brandão (1618);

g) as Cartas dos missionários jesuítas escritas nos dois primeiros séculos de catequese;

h) o Diálogo sobre a Conversão dos Gentios do Pe. Manuel da Nóbrega;

i) a História do Brasil de Fr. Vicente do Salvador (1627) (BOSI, 2017, p. 14).

Os títulos acima, quando analisados individualmente, apresentam a temática do sujeito indígena à luz dos interesses do projeto de colonização da modernidade europeia, ignorando as diferenças étnicas e buscando sistematicamente unificá-la sob o jugo da sua radical identidade.

Além dos textos fundacionais, citados acima, a História oficial é também exemplo de instituição educacional que contribuiu para a consagração do sujeito indígena à margem da vida política no país. Santos 
e Felippe (2018) apontam que os conceitos de vítimas e resistentes atribuídos aos povos indígenas foram lidos respectivamente sob o signo da passividade e da imutabilidade.

Segundo os autores, os povos indígenas no país não sofreram na colonização perdas territoriais gratuitamente, senão que lutaram, fizeram acordos políticos direcionados aos seus interesses vigentes. Assim, não é possível dizer que os povos indígenas no período da colonização não tiveram atuação direta na política que se configurava no Império, sendo, portanto, atores tanto quanto os portugueses e os espanhóis. Sá (2012) também argumenta que:

Embora não haja dúvidas sobre o profundo desequilíbrio de poder entre os principais atores desse confronto, o processo não pode ser descrito como pura e simples imposição de um sistema cultural sobre outro. Desde os primeiros momentos de contato, os povos da Floresta Amazônica e das planícies da América do Sul resistiram à invasão, registrando, como podemos ver em vários depoimentos, um claro ceticismo em relação à suposta superioridade cultural dos europeus. Quando impostas, as práticas religiosas e culturais dos invasores raramente foram aceitas inteiramente, tendo sido frequentemente adaptadas e modificadas para se ajustar às necessidades e crenças indígenas. Ao mesmo tempo, o conhecimento e os modos de vida da floresta deixaram uma marca definitiva na Europa e nas novas nações da América (SÁ, 2012, p. 19-20).

Outra imagem bastante difundida nos dias de hoje advém do conceito de resistência cultural, que surge de uma revisão historiográfica a partir do materialismo histórico que, segundo os autores, buscava "a história vista de baixo" (SANTOS; FELIPPE, 2018, p. 23). Sobre o conceito de resistência cultural, os autores afirmam que:

Segundo essa concepção, para encontrar o indígena resistente, não era necessário evidenciar as expressões escritas pelos próprios, mas, sim, inverter a leitura vigente até então: onde os indígenas eram vistos como vítimas no processo da Conquista, deveriam ser lidos como representantes da resistência cultural. Surgiu, dessa forma, a noção da cultura indígena como algo cristalizado e imutável, na qual as novidades trazidas pelo conquistador ibérico, fossem impostas ou não, deveriam ser rechaçadas. Nessa concepção historiográfica, qualquer novidade externa era vista como ameaça à manutenção da cultura nativa. Reafirmava-se aqui a ideia das culturas tradicionais como impermeáveis às mudanças (SANTOS; FELIPPE, 2018, p. 23). 
Nesse sentido, nota-se que a revisão historiográfica sobre os silêncios, as invisibilidades e as sombras dos atores políticos indígenas causou a imagem da imutabilidade, a ideia de que os sujeitos deveriam ser preservados como animais em extinção, cujo espaço e tempo consolida-se na imagem do "índio" exótico.

Seguindo esse rastro de desarticulação das tradições ameríndias, Viveiros de Castro (2017), ao analisar o texto Sermão do Espírito Santo do Padre Antônio Vieira, afirma que a elaboração do imperador da língua portuguesa, assim coroado por Fernando Pessoa, lança a metáfora da murta sobre os indígenas, que traduzida significa: "[...] o gentio do país era exasperadoramente difícil de converter" (VIVEIROS DE CASTRO, 2017, p. 160), isto é, os "índios" possuíam uma inconstante alma selvagem. Para o autor, tal estigma terá desdobramentos e configurará na identificação inventada aos povos originários:

Essa proverbial inconstância não foi registrada apenas para as coisas da fé. Ela passou, na verdade, a ser um traço definidor do caráter ameríndio, consolidando-se como um dos estereótipos do imaginário nacional: o índio mal-converso que, à primeira oportunidade, mande Deus, enxadas e roupas ao diabo, retornando feliz à selva, presa de um atavismo incurável. A inconstância é uma constante da equação selvagem (VIVEIROS DE CASTRO, 2017, p. 162).

Essa equação difundida pelo imperador da palavra ainda é exaustivamente estudada nas salas de aula, estando presente nos currículos dos cursos de Letras, mantendo-se como referência principal na formação cultural do país. O problema não está em estudar os textos do Padre Vieira na educação de nível básico ou superior, mas estudá-los sem contraponto das respectivas estruturas indígenas ou, ainda, sem situar o tempo, espaço, projeto em que se insere tais textos $v s$. onde se encontra a palavra verbal ameríndia.

Risério (1993, p. 40), em seu livro de ensaios Textos e Tribos, diante da procura da arte verbal ameríndia, denuncia o silenciamento, a traição e o falseamento da poética indígena por parte dos missionários. O autor analisa a indistinção feita por Gonçalves Dias, poeta do indianismo romântico, às tradições do grupo jê e tupi. Com efeito, ao representar no poema Y-Jucá Pirama duas tradições diversas entre si enquanto possuindo uma identidade homogênea, gera a equivocada noção de que todos os povos indígenas possuem uma mesma tradição ancestral:

Y-Jucá Pirama (Dias) encerra uma anedota exemplar. Embora a ação se passe entre os timbira do grupo jê, Dias usou um vocabulário tupi. Além disso, o ritual da morte, ali tematizado, foi extraído da velha narrativa de Hans Staden - e é, como todos sabem, um ritual tupinambá. Por tudo isso, melhor arquivar rótulos 
mistificadores. O verdadeiro poeta dos índios cantava em sua aldeia (RISÉRIO, 1993, p. 51).

O grande problema que podemos destacar para revisão na história da literatura está citado acima. Enquanto parte do cânone, o texto literário de Gonçalves Dias, o não-poeta dos “índios", é estudado como referência poética e literária sem alusão às tradições dos povos citados, timbira (grupo linguístico jê) ou tupinambá (grupo linguístico tupi). Para o autor, "[...] O fato dos textos extraeuropeus não terem conhecido a codificação escrita levou o grafocentrismo a relegá-los a um plano civilizacional inferior" (RISÉRIO, 1993, p. 51), criando estereótipos e imagens que à medida que iam se consolidando, justificavam cada vez mais a expropriação das terras e das almas indígenas.

O reconhecimento do texto criativo ameríndio, para este caso o texto oral, como extraocidental nos permite pensar, na contemporaneidade, sobre a edição dos textos indígenas. Os textos literários indígenas, adentrando no universo da codificação escrita alfabética e da publicação, não negam suas referências culturais, senão que buscam nela a principal matéria para seus livros.

Antes do advento da autoria indígena, diferentes culturas e povos indígenas foram utilizados como tema central dos textos literários brasileiros. O Padre Antônio Vieira, Gonçalves Dias e José de Alencar, por exemplo, tomaram o elemento indígena como referência para imprimir sua mensagem na cultura nacional. Nela, o sujeito ameríndio foi, respectivamente aos autores citados, considerado pagão, pois, como a murta, a alma indígena logo se desconfiguraria; colocado como igual e homogêneo, equívoco naturalizado no país: os grupos timbira e tupinambá, de troncos linguísticos e cosmologias diversos entre si, foram absolutamente desconsiderados em suas diferenças a ponto de o Instituto Socioambiental (ISA) ${ }^{7}$ apontar em sua página inicial sobre a etnia timbira, que o poeta não pode ser assumido como referência ao grupo étnico; José de Alencar, por sua vez, consolidou a imagem do bom selvagem, à luz dos moldes europeus. Neste caso, o indígena foi usado como símbolo do movimento literário indianista e desprovido de qualquer identidade, tendo como destino a submissão à coroa portuguesa e sua religião cristã.

Os exemplos usados nos levam ao questionamento da representação do sujeito indígena na história da literatura brasileira, considerando que "[...] a intertextualidade com a literatura indígena por si só não garante o compromisso com a causa indígena" (SÁ, 2012, p. 31 ). Ou seja, citar o sujeito indígena como elemento exótico, canibal, ingênuo, vítima passiva, resistente à civilização, não colabora para o conhecimento de diversas etnias, modos de vida, tradições existentes no país, mas sim para a recusa, ojeriza e negação desses povos no imaginário da cultura nacional.

Às vezes, porém, as culturas indígenas aparecem como referência de resistência - no sentido de problematização da territorialidade e da identidade indígena no país - na literatura brasileira, e esse é o caso do

\footnotetext{
7 “Timbira”. Disponível em: https://pib.socioambiental.org/pt/Povo:Timbira. Acesso em 27/07/2019.
} 
conto de Guimarães Rosa, Meu tio o lauaretê. Este conto, conforme Sá (2012, p. 30), afirma a "[...] capacidade de resistência do protagonista mestiço em sua luta contra a sociedade em sua volta, uma sociedade marcadamente hostil à sua herança indígena, representada no conto pela onça, animal totem de sua tribo materna". Sobre o "índio" utilizado como referência - tal como por Guimarães Rosa no conto Meu tio lauaretê; e, por outro lado, como autorreferencial na literatura de autoria indígena em que estão explícitas como se relacionam com a natureza -, discutiremos a seguir.

\section{A referência ao e a autorreferência do sujeito indígena na literatura brasileira: a estrutura de homem integrado à natureza como princípio literário}

O conto de Guimarães Rosa, Meu tio o lauaretê, foi publicado em 1961. O enredo denuncia o avanço das fronteiras agrícolas no sertão através da metáfora do homem-onça que é assassinado no desfecho do conto. Além disso, encontramos em Meu tio o lauaretê uma referência para problematizar o lugar da identidade indígena na literatura brasileira e, ao mesmo tempo, para refletir sobre como "[...] os limites do universalismo ocidental e a ameaça que ele representa para outras culturas" (SÁ, 2012, p. 30) podem refletir na imagem representada do sujeito indígena.

Quando a literatura brasileira insiste de modo veemente na reprodução da visão da estrutura ocidental, ela fatalmente conduz o leitor à imagem reducionista difundida e aceita no imaginário da cultura nacional, a saber, como viemos argumentando, a de bom selvagem, canibal, índio, vítima, resistente. Tal definição e invenção circunda a expressão dos sujeitos e povos originários, seja no campo material, seja na esfera simbólica no país.

Por isso, importante destacar a atuação do escritor Guimarães Rosa (1908-1967) e a intertextualidade com fontes indígenas em seu conto, desde a metamorfose do herói em onça até vocábulos da língua tupiguarani. Importante ressaltar, sobretudo, a representação do personagem principal. Esta suscita discussões sobre os povos e sujeitos indígenas, superando a imagem reducionista imposta sobre eles por outros autores na literatura brasileira. O enredo de Meu tio o lauaretê se traduz do seguinte modo:

O conto é a história de um mestiço, meio índio e meio branco, contratado para caçar onças, tarefa que ele, de início, desempenha com competência. Com o tempo, passa a se transformar periodicamente em onça, apaixona-se por uma onça fêmea e termina por matar a maioria dos seres humanos da região. Depois de se transformar em onça pela última vez, é morto por seu interlocutor, isto é, pela pessoa a quem está contando a história (SÁ, 2012, p. 210). 
A identificação da personagem principal, nomeado de Bacuriquirepa, ou Antonho de Eiesus (Antônio de Jesus), ou Breó (Beró), ou Tonho Tigreiro, ou Macuncozo, com a cultura indígena apresenta-se na paixão pela onça fêmea chamada de Maria-Maria:

A onça por quem o protagonista de Guimarães Rosa se apaixona chama-se Maria-Maria, uma variação do nome de sua mãe: Mar'Iara-Maria (que combina, por sua vez, o nome cristão Maria e o indígena Iara, ou Uiara, a Mãe das Águas tupi). Ao se apaixonar por uma onça e se transformar ele mesmo em onça, o sobrinho do Iauaretê passa a se identificar com a cultura indígena de sua mãe, isto é, com os ancestrais totêmicos dos kaingangs, dos mbyá-guaranis e de outros grupos das planícies da América do Sul: 'Mas eu sou onça. Jaguaretê tio meu, irmão de minha mãe, tutira... Meus parentes! Meus parentes"' (SÁ, 2012, p. 213).

Há muitos elementos de identificação com a cultura indígena, desde os excertos da língua tupi: "[...] há mais de uma centena de termos, expressões ou fragmentos do tupi" (NOGUEIRA, 2013, p. 3), à referência a identidade da mãe pertencente ao povo tacunapéua, até a metamorfose em onça. A metamorfose em onça é uma crença comum nas planícies da América do Sul, para Alfred Metraux (apud SÁ, 2012, p. 211):

É uma crença comum na região amazônica que feiticeiros vagueiam pela noite transformados em onça a fim de atacar seus inimigos. Não fica claro, no entanto, se é o próprio feiticeiro que se transforma em onça, ou se ele manda a sua alma para incitar onças de verdade a atacar suas vítimas. A crença em homens-onça era particularmente forte entre os antigos abipóns. No Paraguai, essa superstição é compartilhada igualmente por índios e mestiços.

A variação dos nomes ao longo da narrativa liga-se umbilicalmente à identidade com a qual a personagem principal vai assumir, e a metamorfose em onça, na inversão vingativa contra a colonização. Sobre o nome explica Sá (2012):

Antes de morrer, transforma-se mais uma vez em onça, e uma das últimas palavras que pronuncia é o nome que Ihe fora dado anos antes, Macuncozo. Antes de chegar à região, tivera vários nomes: Bacuriquirepa, seu nome indígena; Beró, outro nome indígena, que significa peró - palavra usada pelos tupinambás para designar os portugueses, e que se refere, no contexto do conto, à sua condição de mestiço; seu nome cristão, Antonho de Eiesús; o nome que Ihe foi dado por Nhô Nhuão Guedes, 
Tonho Tigreiro; e Macuncozo, "nome que era de um sítio que era de outro dono, é - um sítio que chamam de Macuncozo". A origem do nome foi explicada por Haroldo de Campos, que recebeu a informação numa carta do próprio Guimarães Rosa: "o macuncozo é uma nota africana, respingada ali no fim. Uma contranota" (1983, p. 75). Macuncozo é, pois, uma identidade falsa, "um sítio que era de outro dono", uma forma pela qual outras pessoas negavam sua ancestralidade indígena, chamando-o de negro. Uma vez que muitas de suas vítimas são negros, podemos dizer que ele está tentando apagar, ao matar negros e brancos, as falsas identidades que o separavam de seus ancestrais indígenas (SÁ, 2012, p. 216).

A citação acima nos mostra que a identidade indígena prevalece no herói do conto. Ao citar, no fim, o nome Macuncozo, segundo a autora, poderia significar uma empatia com os negros que, como a identidade dele, ficam à margem da sociedade "[...] cujas regras eram sempre ditadas e estabelecidas pelos Nhôs Nhuão Guedes" (SÁ, 2012, p. 216). Sobre a metamorfose em onça e o assassínio da maioria dos homens na região, a autora conclui que:

A violência perpetrada pelo protagonista inverte a violência dos colonizadores contra os índios, sendo, pois, um ato de vingança. Não por acaso o protagonista afirma não desgostar de suas vítimas: ele está repetindo, nisso também, o comportamento do colonizador europeu, que tantas vezes descreveu os índios de forma positiva, sem deixar, no entanto, de querer eliminá-lo (SÁ, 2012, p. 215).

Essa dupla direção, da identidade e da metamorfose apresentadas acima, articula referências aos povos indígenas do país. Este projeto literário de Guimarães Rosa, via conto, reitera um compromisso com a causa indígena. Com efeito, refletir sobre a identidade negra e indígena no texto literário significa também problematizar tais identidades na vida social e política do país.

Como dito anteriormente, não se sabe quais as influências precisas deram ao autor de $\mathrm{Meu}$ tio o lauaretê o material para a composição da obra, mas, como podemos perceber no texto, a estrutura natureza versus cultura não dissolve a identidade tradicional ameríndia em detrimento da identidade moderna, senão que evidencia seu lugar, sua língua e seu futuro, nessa mesma estrutura.

Assim, o conto não faz a manutenção da imagem caricata lançada inequívoca e secularmente sobre os indígenas brasileiros, senão que fomenta temas cosmológicos, como a metamorfose em homem-onça; culturais, como a busca pela identidade e voz indígena; políticas, como o avanço das fronteiras agrícolas na região do sertão; e, ainda, como a 
referência às tradições indígenas podem ser usadas de modo consciente enquanto material para o processo criativo literário de escritores brasileiros.

Como matéria, as tradições indígenas foram usadas historicamente para o arranjo de textos literários, mas agora os povos, em caráter coletivo, e os sujeitos, em caráter individual, passam a se valer de suas histórias ancestrais - desde as de origem sagradas - a fim de mesclá-las às histórias do cotidiano que narram modos de vida, para composição de seus enredos criativos e literários. Em Meu destino é ser onça, Alberto Mussa (2009) afirma que as narrativas míticas constituem o gênero literário por excelência:

Um mito é necessariamente uma peça estética, cheia de metáforas e de processos narrativos que visam entreter e provocar emoções. Ao mesmo tempo - e também necessariamente - é um discurso teórico, que explica e defende uma certa tese sobre o homem ou a natureza (MUSSA, 2009, p. 71).

Essa peça estética, cheia de metáforas e de processos narrativos, é a principal matéria para os textos criativos ameríndios publicados em caráter individual e também coletivos (Cf.: ALMEIDA; QUEIROZ, 2004) desde a década de 1990 no Brasil. Assim, seguindo a lógica de suas culturas, os autores baseiam-se nela como principal referência para a manufaturação de um livro dito literário.

Se o movimento literário indianista utilizou-se da imagem do índio - inventado e solidificado enquanto exótico -, agora os sujeitos indígenas retomam a palavra, através da autoria, para ressignificar imagens construídas sobre si, cuja referência extemporânea sobre eles se baseou nos ideais da modernidade; bem como para evitar a mediação histórica entre os povos e a sociedade envolvente. Kaká Werá (2017), ao teorizar sobre a literatura indígena, reitera a importância da assunção da autoria desde os próprios indígenas, posto que o seu lugar de fala sempre foi, historicamente, mediado por outrem que não o indígena:

[...] Então nós sonhamos, naquela época não era ainda criar um movimento de literatura indígena, mas em usar a escrita para falar de nossas culturas. Para falar diretamente. Para se ter uma ideia, até o início dos anos 1990, o que se tem notícia é de que praticamente tudo o que existe de escrito no Brasil sobre o índio, sobre os povos indígenas, sobre as culturas indígenas, não foi escrito por um índio. Sempre foi por um indigenista, por um antropólogo, por um sociólogo, por um estudioso, por um artista, por um poeta, por um escritor. Não que eu ache que isso seja uma coisa errada. Mas eu achava que, na medida em que nós nos tornássemos protagonistas das nossas próprias vozes, isso poderia gerar uma força muito grande, uma estratégia muito 
potente para se comunicar diretamente com a sociedade. E também para a sociedade ouvir diretamente a voz de um intelectual, de um cidadão, de um pensador, de um curador, de um contador de histórias vindo de um povo indígena. Na verdade, não é que isso represente alguma coisa nova. A tradição indígena é uma tradição literária, é uma tradição poética, é uma tradição artística (WERÁ, 2017, p. 26).

O domínio de técnicas como a escrita alfabética é, como podemos perceber na fala acima, um instrumento utilizado de modo direto pelos autores indígenas para dialogar com a sociedade brasileira e para ressignificar noções ossificadas no imaginário ocidentalizado de que sociedades tradicionais e orais não possuem literatura.

Se a literatura indígena é reconhecida no país somente a partir do momento em que ela passa a ter materializada a edição dos textos coletivos e individuais, para Werá (2017), desde longa data ela faz parte da configuração cultural dos povos e está alinhada às concepções de mundo, de estrutura, em caráter extraocidental.

Ailton Krenak (2017) argumenta que na matriz dos pensamentos dos povos originários, a estética não está dissociada da vida cotidiana:

[...] Ser criativo, ser ativo, criar. É arte. [...] Todo mundo que eu conheço dança, canta, pinta, desenha, esculpe, faz tudo isso que o Ocidente atribui a uma categoria de gente, que são os artistas. Só que em alguns casos são chamados de artesãos e suas obras são chamadas de artesanato, mas de novo, são categorias que discriminam o que é arte, o que é artesanato, o que é um artista, o que é um artesão. Porque a história da arte é a história da arte do Ocidente (KRENAK, 2017, p. 78).

A noção de que os povos tradicionais são naturalmente sociedades estéticas, artísticas e literárias está muito difundida entre lideranças, ativistas e escritores indígenas. Assim, Daniel Munduruku (2017) define o conceito de literatura indígena para além da publicação de livros: ela é a atualização da memória pelo escrito, mas sem deixar se resumir a essa escrita alfabética e ao impresso. Por isso mesmo, o autor argumenta que:

$\mathrm{Na}$ compreensão que temos desenvolvido, esse instrumento engloba muito mais que o texto escrito, ele abrange diversas manifestações culturais, como a dança, o canto, o grafismo, as preces e as narrativas tradicionais (MUNDURUKU, 2017, p. 122).

Como as referências culturais são trazidas para dentro dos textos dos autores, vemos que o formato, a mensagem, o gênero são adaptados em função de seus projetos individuais, mas inextricáveis da pertença étnica. No entanto, nesse conjunto de obras nota-se que o princípio de 
homem integrado à natureza orienta as produções indígenas nas diferentes tradições e pertenças étnicas de seus autores, a fim de impulsionar a escrita autorreferenciada como crítica à modernização.

Em outras palavras, se a escrita alfabética e o conceito de literatura são marcas do Ocidente, quando tomadas pelos povos indígenas, -que são concebidos desde uma perspectiva cientificista como povos de oralidade e que não possuem a literatura - fazem dialogar diferentes tradições - ocidental e indígena - em favor de sua identidade e pelo direito à existência por meio da arte.

Em Nós somos só filhos, de Sulamy Katy (2011), por exemplo, vemos no texto literário a defesa do território, o orgulho da pertença étnica e a crítica à estrutura ocidental que dicotomiza as relações entre natureza e cultura. Seu texto diz o seguinte:

Nós somos os filhos do tempo, do vento e do anoitecer. Sentimos a dor de pestanas arrancadas, atolamos em mangue para pegar caranguejo, levamos surra de urtiga, dormimos em rede ou esteira e, mesmo que ainda cansados, esperamos diariamente a noite que traz os gritos do mar parindo uma lua brilhante.

[...] Nós somos filhos do ar!

Nós somos filhos da água, da mata e do entardecer.

Vemos a vida com a visão dos que nascem no meio das pedras tendo a palha do Ouricuri como ninho que, para ser visto, tem que ser tingido de negro e, dessa forma, nossa gente obtém o direito de pertencer.

O sangue de nossos antepassados adubou nossa terra, fez nascer o urucum, que quando é pintado em nosso corpo deixa nosso espírito livre para voar sobre a terra encantada, dançar ao redor da fogueira sagrada das festas do nosso povo que com um sorriso de prata, ilumina a mata inteira e nos traz o amanhecer.

Nós somos filhos do fogo!

E sabemos que o melhor de tudo isso é que

Nós somos só filhos! (KATY, 2011, s/p).

No texto literário de Sulamy Katy (2011), a questão da territorialidade ameríndia é o eixo que orienta a reflexão sobre as visões autóctone e ocidental do mundo. De acordo com Olivieri-Godet (2017, p. 2-3), do referente às representações, do topos ao logos, os textos literários indígenas exploram a dimensão espacial considerada nas suas vertentes material e simbólica que remetem, respectivamente, aos aspectos geográficos, históricos e sociais da habitabilidade dos territórios ameríndios e às figurações de (re)apropriação cultural.

A autora constata que a referência primordial dos povos autóctones passa pela relação com o território que consiste numa relação orgânica, política, social, vital com a terra, tal como pudemos observar acima.

Se nos textos romântico-indianistas, o sujeito indígena é vilipendiado por ter essa relação orgânica com a natureza, aqui ele se 
torna protagonista dessa relação, posto que na agenda contemporânea a preservação da terra e dos rios, da floresta, ganhou destaque na economia ocidental.

Desse modo, em Kaká Werá Jecupé (2002), o sentido da emergência da literatura de autoria indígena está na urgência em proteger a natureza, responsável por prover vida aos povos indígenas e não indígenas:

É esse o sentido de contar o que tenho para contar. Os seres da natureza e a Grande Mãe temem e sopram aos nossos olhos e ouvidos uma urgência. A tradição milenar que compôs meu espírito tem mantido a minha sobrevivência e a de meu povo. Agora, porém, não é a de minha vida nem a de meu povo que está em jogo. É a de todos. É a das culturas e nações semeadas pela extensão do carinho e da enorme bondade dessa Mãe a que chamam Terra. Por isso eu passo a ser também a voz que partilha um aprendizado (JECUPÉ, 2002, p. 17).

Na mesma esteira, Daniel Munduruku (2016) reitera essa relação do homem indígena à natureza explicitando as diferentes relações que se constituem a partir desse princípio:

O indígena sempre foi um filho da terra. É no solo sagrado da mãe Terra que ele vive suas tradições; é dos cabelos da mãe Natureza que o indígena se alimenta, tira a matéria-prima para construir sua casa, fabricar seus arcos e flechas, enterrar seus mortos, celebrar a vida. No entanto, a terra é o bem que ele vê mais ameaçado pelos não indígenas (MUNDURUKU, 2016, p. 60).

Ailton Krenak (2019) também expressa sua compreensão de homem indígena integrado à natureza. Ele reforça em sua declaração a dimensão dessa relação, nela não há separação e a natureza não está dissociada da vida, da humanidade do autor: "[...] Eu não percebo onde tem alguma coisa que não seja natureza. Tudo é natureza. O cosmos é natureza. Tudo em que eu consigo pensar é natureza" (KRENAK, 2019, p. 17). Esse princípio orienta os planos de ação do povo Krenak e é a partir dela que se configuram ações cotidianas e, também, as mensagens enunciadas pelos autores indígenas, como este trecho que faz parte do livro publicado pela liderança indígena Ailton Krenak:

Tem uma montanha rochosa na região onde o rio Doce foi atingido pela lama da mineração. A aldeia Krenak fica na margem esquerda do rio, na direita tem uma serra. Aprendi que aquela serra tem nome, Takukrak, e personalidade. De manhã cedo, de lá do terreiro da aldeia, as pessoas olham para ela e sabem se o dia vai ser bom ou se é melhor ficar quieto. Quando ela está com uma cara do tipo "não estou para conversa hoje", as pessoas já ficam atentas. Quando ela amanhece 
esplêndida, bonita, com nuvens claras sobrevoando a sua cabeça, toda enfeitada, o pessoal fala: "Pode fazer festa, dançar, pescar, pode fazer o que quiser (KRENAK, 2019, p. 17-18).

A relação homem e natureza, nesse sentido, é considerada por Krenak (2017) como necessária, uma vez que o homem moderno deixa de ver a Mãe Terra como sagrada, passando a enxergá-la apenas como recurso:

[...] Nós compartilhamos uma grande canoa - eu insisto nessa imagem -, na qual a qualidade do ambiente não é mais uma preocupação da maioria da tripulação, porque os artifícios que foram acessados, as técnicas, os recursos, a tecnologia, isso que nós chamamos de tecnologia, que foi acessada pelos humanos, rompe aquela relação de lugar sagrado da Terra, que o Olimpo teve um dia e que outros lugares continuaram a ter mais tarde. Seus habitantes romperam com a ideia de que aqueles lugares eram sagrados e passaram também a tratar aqueles lugares como recurso (KRENAK, 2017, p. 72).

Esse princípio de homem e natureza possui uma história objetiva, assentada nos saberes ancestrais passados oralmente de tradição em tradição, que orienta as comunidades indígenas reivindicando o direito de viver conforme suas espiritualidades e modos de vida, ao lado de outros grupos que dão sentido ao mundo de modo diverso ao do Ocidente. Para Escobar (2015):

[...] el entendimiento del mundo es mucho más amplio que el entendimiento occidental del mundo. Esto significa que la transformación del mundo y las transiciones hacia el pluriverso, o las transformaciones iluminadas por activistas campesinos, indígenas, y afrodescendientes, pueden ocurrir (de hecho están ocurriendo) a través de vías impensables desde las teorías eurocêntricas (ESCOBAR, 2015, p. 16).

Os modos de viver de grupos-outros e sua relação com a terra têm dado o tom para uma crítica às correntes eurocêntricas e seus projetos modernizadores/colonizadores do mundo. Tais críticas passam a pulular nos textos literários indígenas porque, como enfatiza Krenak (apud COHN, 2015):

Na nossa tradição, na tradição indígena, nós temos uma história - a história da fundação do mundo - que nos integra no que poderia ser considerado o universo. Os fatos dessa história se aproximariam muito dos eventos religiosos. Nós temos uma história que poderíamos 
chamar de história objetiva, história do mundo, sobre a qual agimos. Nós agimos no mundo, mas somos filhos de uma tradição em que o nosso poder é limitado (COHN, 2015, p. 91-92).

O sujeito indígena não se comporta como o dono da natureza, mas como filho ou guardião dela. A literatura de autoria indígena denota essa relação nos textos criativos de alguns autores que se valem do arcabouço narrativo de seu povo para contar ao não indígena suas histórias de origem. Da tradição ancestral e oral ao texto escrito em língua portuguesa e alfabética, os autores indígenas reiteram o sentimento do coletivo, do amor à natureza, da sua pertença étnica:

Takalulu vivia sozinho no mundo. Queria muito encontrar uma mulher e muitas outras pessoas para lhe fazer companhia. Então começou a cantar, cantar e cantar, e foi cavoucando, cavoucando um buraco no chão. De dentro do buraco, ele ia jogando para fora bolinhas de terra mole. E cada uma dessas bolinhas se transformava numa pessoa (KITHÃULU, 2002, p. 9).

A origem do homem nambikwara, etnia do escritor Renê Khitãulu, se dá a partir da terra, da terra mole que Takalulu joga para fora do buraco. O homem nambikwara vem da Terra, e dela ele faz parte como se pode observar no excerto acima. Graúna (2013), nesse diapasão, argumenta que "[...] no contexto contemporâneo, o despertar literário dos povos indígenas no Brasil não está dissociado da oralidade, da razão dos mitos" (GRAÚNA, 2013 , p. 168).

Orientados pela visão tradicional, ou estrutural de homem integrado à natureza, os autores, intelectuais, artistas e lideranças indígenas têm cada vez mais apresentado suas formas de dar sentido ao mundo, mostrando que nela a dicotomia natureza versus cultura não corresponde ao único modelo econômico, político e social de vida. Para finalizar, apresentamos a leitura de Graúna (2013) sobre a literatura indígena brasileira contemporânea:

As vozes ancestrais sugerem mais e mais desafios que emanam da literatura indígena contemporânea: um mundo espelhado de mundos, de sonhos e realidades distintas; um mundo de pessoas que foram impedidas de expressar o seu pensamento ao longo dos mais de 500 anos de colonização (GRAÚNA, 2013, p. 170).

Se a manifestação oral não foi levada em consideração, se as alianças indígenas e políticas junto aos europeus não foram consideradas na História oficial, agora os sujeitos originários retomam a palavra para dar materialidade à voz silenciada nesses cinco séculos de colonização. Elas anunciam seu protagonismo desde a chegada dos portugueses, denunciam o exílio físico e epistemológico através dos tempos, e 
apresentam uma nova poética, a poética ameríndia, cujo tom exalta a relação natureza e a cultura.

Assim, se seu modo de vida foi tomado pelo projeto da modernidade como inferior, marginal, subalterno, seu modo de vida hoje é afirmado desde os próprios indígenas, e também por teóricos das Epistemologias do Sul e da Decolonialidade como resposta possível aos problemas do Antropoceno, das relações humanas (eu versus nós), e da expressão da arte.

Nessa tensão de estruturas, indígena e ocidental, vemos que a história da literatura ecoa os traços das tradições eurocêntricas, do romantismo-indianista até obras mais contemporâneas, em que vemos a tradição ocidental representar o sujeito indígena no lugar reservado a ele de subalterno; em Sulamy Katy, Ailton Krenak, Daniel Munduruku, Renê Khitãulu, vemos a escrita literária e teórica autorreferenciada ser representada com orgulho da pertença étnica, desvelando que as diferentes culturas têm seus valores normativos e ela segue o princípio de homem como filho da natureza e não como "dono" dela.

\section{Considerações Finais}

A autoria indígena, como mote central da literatura indígena, evidencia um sistema literário que se desenha a cada nova publicação dos povos e sujeitos tradicionais. Com efeito, pudemos perceber que, até a década de 1990, as tradições e os sujeitos originários foram representados por outrem, pelo não indígena.

Em alguns casos, a exemplo de Guimarães Rosa, a referência a essas tradições colaborou para uma reflexão sobre o lugar e o destino dos povos ameríndios na cultura e na sociedade brasileira. Em outros, na maioria, constituíram uma sólida distância de suas culturas e modos de vida.

Será na autorreferência autoral, portanto, que as diferentes formas de dar sentido ao mundo, mais alinhadas com suas ontologias, se tornarão mais sensíveis e críveis ao leitor; aqui, os autores indígenas demonstram suas referências culturais em vocábulos, crenças, língua, cotidiano de suas aldeias, etc. Assim, por meio de seus livros literários, ensejam sua tradição (oral), sua estrutura de homem vinculado à natureza (e não a de cultura versus a natureza), em diálogo e crítica à modernidade (escrita).

Ainda inscrevem a História indígena por meio da memória, da autobiografia e do testemunho recontando o contato e as consequências da colonização ainda nos dias de hoje. Recontam que não são ingênuos, canibais, vítimas passivas ou resistentes (e inflexíveis) às tecnologias e a diferentes culturas, mas que, em sua própria história, são protagonistas de seus enredos: isto eles já sabem, contam ao não indígena para que aprendam também.

As diferentes lições que a literatura indígena apresenta no nosso presente devem ser tomadas como aliadas para repensarmos as 
diferenças no ensino do curso de Letras e outros cursos das Ciências Humanas. A poética indígena, que nasce em outra tradição, extraocidental, não europeia, deve ser compreendida enquanto uma outra estrutura, outra alternativa de dar sentido ao mundo, já que estamos, como diz Krenak (2017), na mesma canoa.

Assim, ao ler um livro de literatura indígena, é preciso escapar do inevitável exercício de reduzi-la à literatura ocidental. Antes, torna-se necessário percebê-la oral, ancestral, pertencente a uma cosmologia específica em diálogo com o escrito (ocidental) e com a sociedade envolvente. Além disso, é imprescindível perceber as diferentes mensagens que cada livro indígena publicado passa à sociedade nacional. Tal exercício pode ser o primeiro para uma compreensão da diferença, das tradições indígenas, da literatura indígena brasileira contemporânea. 


\section{Referências Bibliográficas}

ALBERT, B. O ouro canibal e a queda do céu. Uma crítica xamânica da economia política da natureza (Yanomami). In: ALBERT, Bruce; RAMOS, Alcida Rita. Pacificando o branco: cosmologias do contato no Norte-Amazônico. São Paulo: Editora UNESP: Imprensa Oficial do Estado, 2002.

ALMEIDA, M; QUEIROZ, Na captura da voz: as edições da narrativa oral no Brasil. Belo Horizonte: Autêntica; FALE/UFMG, 2004.

BOSI, A. História concisa da literatura brasileira. 51. Ed. São Paulo: Cultrix, 2017.

COHN, S (org). Ailton Krenak. Rio de Janeiro: Editora Azougue, 2015.

CUNHA, M. C. Índios no Brasil: história, direitos e cidadania. São Paulo: Claro Enigma, 2012.

DANNER, L. F.; DANNER, F.; BAVARESCO, A. "O colonialismo como teoria da modernidade: esboço de uma pesquisa interdisciplinar em teoria social crítica”. In: Ágora Filosófica, Ano 17, n. 1, jan/jun., p. 149-251, Universidade Católica de Pernambuco, 2017.

DESCOLA, P. Outras naturezas, outras culturas. Tradução de Cecília Ciscato. São Paulo: Editora 34, 2016 (1ª Edição).

ESCOBAR, A. "Sentipensar con la Tierra: las Luchas Territoriales y la Dimensión Ontológica de las Epistemologias del Sur". In: Revista de Antropología Iberoamericana. Volumen 11, Número 1, Enero - abril, p. 11-32, Madrid, 2016. Acesso em 17 de dezembro de 2018.

FERNANDES, E. R. Ruptura epistêmica, Decolonialidade e Povos Indígenas: Reflexões sobre Saberes-Outros. In: DANNER, Fernando; DANNER, Leno Francisco (org). Ensino de filosofia, gênero e diversidade. Porto Alegre: Editora FI, 2014, p. 52-72.

GAMBINI, R. Espelho índio: a formação da alma brasileira. Coordenação Mary Lou Paris, Caio Kugelmas. São Paulo: Axis Mundi: Terceiro Nome, 2000.

GANDAVO, P. de M. Tratado da Terra do Brasil: história da Província de Santa Cruz. Belo Horizonte: Ed. Itatiaia, São Paulo: Ed. da Universidade de São Paulo, 1980.

GRAÚNA, G. Contrapontos da literatura indígena contemporânea no Brasil. Belo Horizonte: Mazza Edições, 2013.

JECUPÉ, K. W. Oré awé roiru'a ma Todas as vezes que dissemos adeus. Fotos Adriano Gambarini. $2^{a}$ ed. rev. e com novas fotos. São Paulo: TRIOM, 2002.

JEKUPÉ, O. A literatura escrita pelos povos nativos. São Paulo: Editora Scortecci, 2009. 
KATY, S. Nós somos só filhos. Ilustrações Maurício Negro. 1 ed. Rio de Janeiro: ZIT, 2011.

KITHÃULU, R. Irakisu: o menino criador. 4 ed. Ilustrações do autor e das crianças Nambikwara. São Paulo: Peirópolis, 2002. (Coleção memórias ancestrais: povo Nambikwara).

KRENAK, A. Ideias para adiar o fim do mundo. 1 ed. São Paulo: Companhia das Letras, 2019.

Ailton Krenak. Rio de Janeiro: Azougue Editorial, 2017. (Coleção Tembetá).

MUNDURUKU, D. Mundurukando 2: sobre vivências, piolhos e afetos: roda de conversa com educadores. Lorena, SP: UK'A Editorial, 2017.

Histórias de índio. Ilustrações Laurabeatriz. $2^{\mathrm{a}}$ ed. São Paulo: Companhia das Letrinhas, 2016.

MUSSA, A. Meu destino é ser onça. Rio de Janeiro: Record, 2009.

NOGUEIRA, E. S. "A voz indígena em "Meu tio, o iauaretê" de Guimarães Rosa". In: Nau Literária: crítica e teoria de literaturas. vol. 9, $\mathrm{n}^{\mathrm{o}}$ 1, jan./jun., p. 1-12. Porto Alegre, 2013.

OLIVIERI-GODET, R. "A emergência de autores ameríndios na literatura brasileira”. In: Ciclo de Debates Cultura Brasileira Contemporânea: novos agentes, novas articulações. Departamento de Teoria literária e literatura comparada (USP), 2017.

RISÉRIO, A. Textos e tribos: poéticas extraocidentais nos trópicos brasileiros. Rio de Janeiro: Imago Ed., 1993.

ROSA, J. G. Estas estórias. 7.ed. Rio de Janeiro: Nova Fronteira, 2015.

SÁ, L. Literaturas da floresta: textos amazônicos e cultura latino-americana. Rio de Janeiro: EdUERJ, 2012.

SANTOS, M. C.; FELIPPE, G. G. Debates sobre a questão indígena: histórias, contatos e saberes. Porto Alegre: EDIPUCRS, 2018.

SHOHAT, E.; STAM, R. Crítica da imagem eurocêntrica: multiculturalismo e representação. São Paulo: Cosac Naify, 2006.

STADEN, H. Duas viagens ao Brasil: primeiros registros sobre o Brasil. Tradução Angel Bojadsen; introdução de Eduardo Bueno. Porto Alegre, RS: L\&PM, 2017.

TREECE, D. Exilados, aliados, rebeldes: o movimento indianista, a política indigenista e o estado-nação imperial. Tradução Fábio Fonseca Melo. São Paulo: Nankin: Edusp, 2008 . 
VIVEIROS DE CASTRO, E. A inconstância da alma selvagem e outros ensaios de antropologia. São Paulo: UBU Editora, 2017.

WERÁ, K (org). Kaká Werá. Rio de Janeiro: Azougue Editorial, 2017.

Recebido em: 01/06/2019* Aprovado em: 16/07/2019* Publicado em: 30/12/2019 